\title{
ENHANCED GEOMORPHIC DESIGN FOR RECLAMATION OF RURAL WASTE-SCAPES
}

\author{
Neeltje Slingerland *, Nicholas A. Beier and G. Ward Wilson \\ Department of Civil and Environmental Engineering, University of Alberta - Edmonton, Alberta, Canada
}

Article Info:

Received:

23 January 2018

Revised:

7 April 2018

Accepted:

11 June 2018

Available online:

30 June 2018

Keywords:

Geomorphology

Geomorphic design

Oil sands

Alberta, Canada

Mine reclamation

\begin{abstract}
Many inventive concepts for the adaptive re-use of waste landscapes, or wastescapes, have been proposed and constructed in the last decade. These are often located near or within large, urban populations, which provide much of the incentive for adaptive re-use. A different challenge presents itself when a waste-scape is rurally located, near a small - though equally important - population. How do we address complex socio-cultural, economic, and environmental objectives without the economic incentive provided by a large nearby population? This project looks at the mineable oil sands region of northern Alberta, Canada: a rural waste-scape covering $895 \mathrm{~km}^{2}$ in Canada's boreal forest. Specifically, this project discusses the geomorphology and native substrate of northern Alberta, juxtaposed with the traditional design of waste storage landforms, in order to show that there are no natural analogues in the region. A geomorphic approach to the design of waste-scapes in this region has been developed using a Landscape Evolution Model (LEM) for longterm projections, and is being tested in the region. This project sheds new light on the rarely acknowledged issue of waste design in rural areas and the wide range of benefits achieved through use of an enhanced geomorphic design approach.
\end{abstract}

\section{INTRODUCTION}

How can we create value from what is traditionally considered a waste landscape or "un-usable" environment? This question has been answered through unique, inventive, and costly approaches where waste landscapes, or waste-scapes, are located near large populations and urban environments: architect Bjarke Ingles' artificial ski hill atop Copenhagen's 'Amager Bakke' waste incinerator, and Lusatia, Germany's new lake district are two popular examples. However, as NIMBY-ism proliferates wastescapes are shifted increasingly towards sensitive rural environments with smaller communities. How do we address complex social and environmental objectives without the economic incentive provided by a large nearby population?

The resource sector, specifically mining, is one with experience in managing waste in rural areas. The waste management and landfilling industry has many overlapping concerns, impacts, and similarities to the mining industry:

- Required life cycle design and planning is a relatively new concept to the industry;

- Topography is altered over long timeframes and large areas;

- Expected and potential environmental impacts demand thorough environmental assessment;
- Possible ground and surface water contamination are long-term risks requiring management;

- High greenhouse gas emissions make carbon taxes significant;

- Regulatory issues are complex and intertwined across disciplines, generating "wicked" problems (Rittel \& Webber 1973);

- New technologies seek to utilize waste as a resource;

- Working with NGO's, managing public perception and involvement is increasingly important.

Waste management is at the core of the mining industry, producing fractions of an ounce to a few ounces of profitable ore per ton of waste generated. In terms of spatial area, the extent of mineral extraction is often dwarfed by the area used to hold mine waste resulting from extraction and mineral processing. These holding areas consist of tailings ponds (where aboveground dams are constructed of mine waste to retain slurried mine waste in a pond), as well as aboveground "dumps" or piles comprised of unprofitable waste rock. The landscape resulting from surface mining - mainly a mined pit, aboveground waste storages, and a processing area - all require reclamation such that the land not pose hazards to human or environmental health.

Mines are frequently located in rural areas with small populations, providing welcome employment opportu- 
nities yet unwelcome residual landscape impacts. It has been estimated that rural communities in Canada rely on resource industries (which includes mining) for greater than 25 percent of their employment (Stedman et al. 2004). Mine waste is often physically and chemically unstable, making reclamation a challenge and frequently leading to prolonged disturbance. As mineralized portions of the substrata are removed from the ground, they are broken into smaller pieces, increasing the surface area exposed and available to react with the environment. Contaminated surface and groundwater discharge as well as excessive and/or contaminated dust are two challenges created through this process. Surface settlement of the waste rock or tailings ponds can also be a long-term challenge for reclamation.

The Athabasca oil sands (AOS) surface mining region in Alberta, Canada has been criticized for its widespread disturbance of the land through mining. In reality, mining occurs over a relatively short time frame (+/- 50 years), and the majority of this 895 square kilometre landscape will be used for waste storage in perpetuity once mining ceases. Reclamation is proposed to take another 10 - 20 years according to closure plans filed in the region, although when reclamation of other smaller mines with less complex waste is considered, this reclamation timeline is likely to be much longer.

For example, Brenda Mine in Penticton, British Columbia, Canada was a small copper and molybdenum mine with an 87 hectare tailngs pond reclaimed from 1988 to 1997. Tailings here do not present the same consolidation problems that exist in oil sands mines. 20 years later (in 2018) the tailings pond presently contains an unreclaimed portion with a water surface, requires that earthen areas be fertilized every two years to maintain vegetation, and will have staffed water treatment facilities long-term. This site is not self-sustaining despite reclamation efforts. In contrast, tailings ponds in the oil sands typically cover 10 times more area than that at Brenda, with more challenging tailings to reclaim. In order to lessen the burden of reclamation regulators, engineers, ecologists, hydrogeologists, and landscape architects have been working collaboratively to develop an economic method of restoring the environment for local populations in an expedited fashion.

The negative consequences typically attributed to mining are more specifically a result of waste management practices throughout the operational phase and in perpetuity thereafter. This paper describes how professionals currently design topography for this waste-scape, as well as an enhanced method of geomorphic design for long-term stability and adaptive re-use.

\section{FORM AS A BASIS FOR LONG-TERM WASTE- SCAPE SUCCESS}

The glossary of geology defines a landscape as "a distinct association of landforms, as operated on by geologic processes (exo- or endogenic), that can be seen in a single view." The concept that a view defines a landscape suggests that it is being inhabited or used by a person (or animal), and that there is a symbiotic exchange occurring between the user and the land as a result. While the AOS region in northern Alberta is certainly rural, it is also the location of historic migratory as well as hunting, trapping, and medicine gathering territory of indigenous Cree and Dene people (Joly et al. 2018; Baker \& Westman, 2018). Today Fort McKay First Nation, a community comprising five Indian reserves and a population of approximately 600 , sits on the shores of the Athabasca River at the center of oil sands development in the region.

A larger community that was originally built around servicing the oil sands mines, their employees, and their families, exists south of the mines in Fort McMurray and currently has a population of just over 60,000 people. Figure 1 illustrates the location of the mines and these communities.

\subsection{Local community}

First Nations have inhabited the Fort McKay area since the early 1800's. They have lived off the land by hunting, fishing, gathering, and also by nurturing the local environment where possible to ensure their sustainable way of life can be continued into the future (Fort McKay website, 2017; Baker \& Westman, 2018; Joly et al. 2018). In recent decades, residents of Fort McKay have worked with industry towards mutually beneficial land and employment agreements (Baker \& Westman, 2018). However, boombust cycles and economic dynamics occassionally leave the community at risk of low employment rates, as well as a full spectrum of positive and negative ramifications. Included in this spectrum are health impacts due to job insecurity stress and environmental degradation, compounded by limited access to health services due to their rural location (Shandro et al. 2011). The return of productive landscape in-line with sustainable indigenous land uses is currently thought to be the most desirable method of supporting local First Nations into the future.

\subsection{The impact associated with geomorphology}

Ideally, local communities pre-existing the mines will be able to continue their way of life within the future reclaimed waste-scape. While the success of the re-designed waste-scape is dependent upon many diverse aspects, the foundation for success can largely be attributed to designing the appropriate landform upon which ecological, chemical, and hydrological, processes may occur. For many years, abandoned mines have been shown to be subject to excess erosion and slope failure, thereby hindering vegetation productivity, local water quality, and return of native fauna (Martin Duque et al. 2015; Toy \& Hadley 1987).

Landforms are altered slowly over time by physical and chemical erosional processes. This paper focuses on physical processes common to a boreal environment: erosion by wind and predominantly water, thereby changing the shape of a landform (Richards \& Clifford 2011). For example, a sand castle may be indistinguishable from the rest of the beach following a storm with high winds and heavy rainfall. The same general processes of wind and water erosion act on the surface of our earth to create mature and increasingly erosion-resistant landforms over time, growing nearer 
to a state of equilibrium with increasing maturity.

In the design of waste-scapes, particularly those generated through mining, efficiency is a primary consideration with respect to the operational life span of the mine. Geotechnical and mining engineers often design the footprint using straight lines and the downstream dykesusing maximum slopes in order to optimize the waste-holding capacity. This engineered form may be easily maintained while the mine is in operation and staff are present; however, on mine closure this form will be more easily degraded by wind and water erosion until it reaches an equilibrium with the forces acting on it - similar to the sand castle during a storm (see Figure 2).

When a landform is eroding due to water runoff or "overland flow", eroded sediment is transported and deposited downslope, impacting the vegetation on both erosional and depositional portions of the slope. On the eroded portion vegetation cannot establish or be maintained, and on the depositional portion, vegetation is buried. In some instances eroded sediment is transported into adjacent water bodies, increasing the sediment load and decreasing water quality. Toy and Osterkamp (1995) go so far as to call human-accelerated erosion a "serious global problem" and "the pre-eminent environmental problem in the United States". Design using a mature form encourages the success of revegetation, minimizes the need for repeated seeding/ planting, and helps to preserve adjacent water quality. Regionally appropriate geomorphic landforms aim to provide topography that would occur after millennia of weathering, therefore the foundation they provide is more stable, and likely to generate microclimates that support local flora and fauna. This is aesthetically beneficial, but it is also important for future land productivity and a return to traditional land uses.

\section{THE ALBERTA OIL SANDS REGION}

\subsection{The native landscape}

In terms of topography, the landscape is naturally low lying around 260 - 350 meters above sea level (m.a.s.l.) and

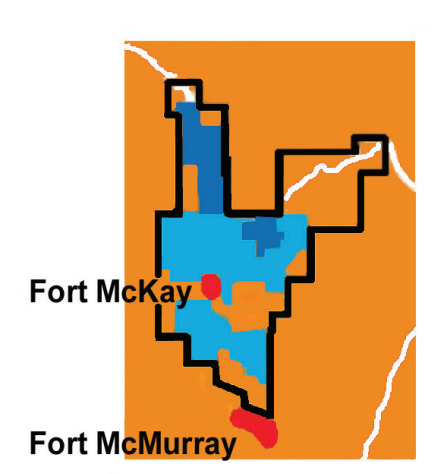

Drawing Not to Scale

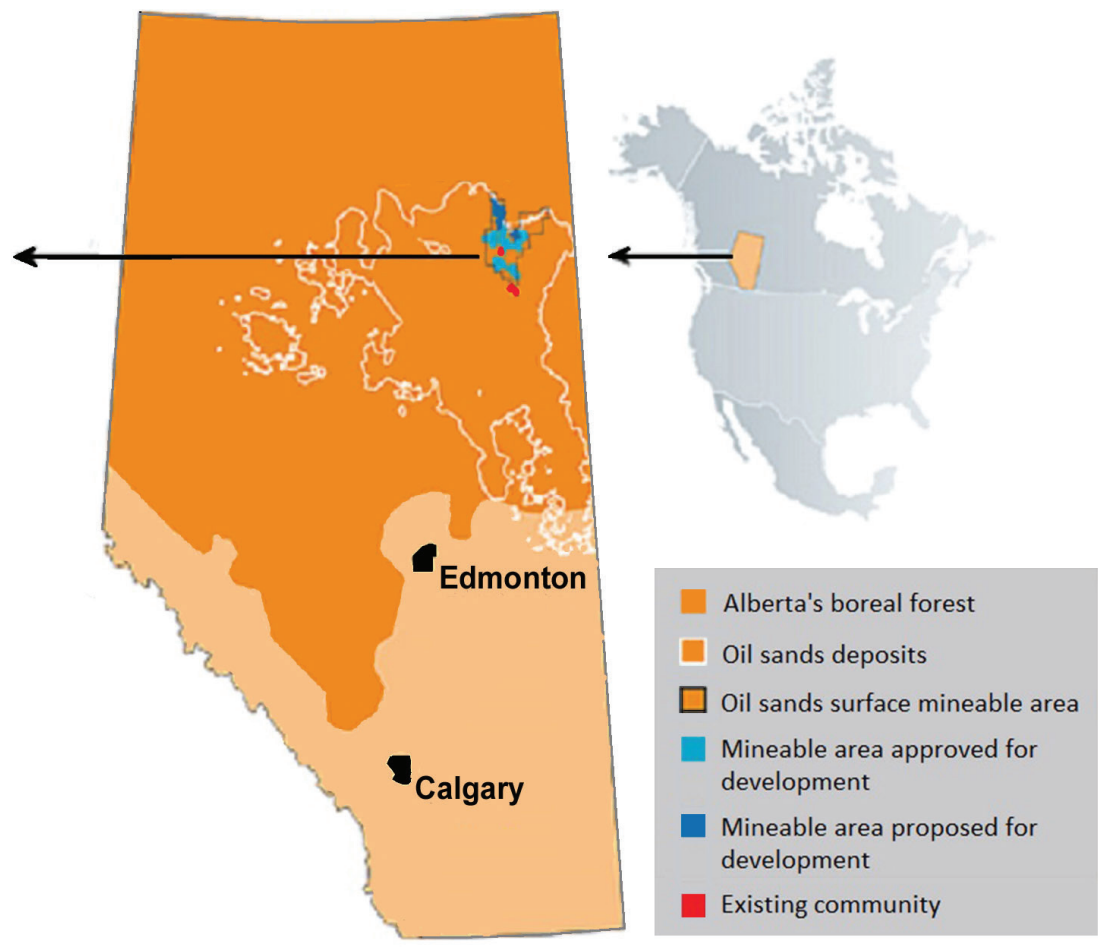

FIGURE 1: Location of mineable oil sands and nearby communities within Alberta, Canada. Adapted from AER (https://www.aer.ca/aboutaer/spotlight-on/oil-sands).
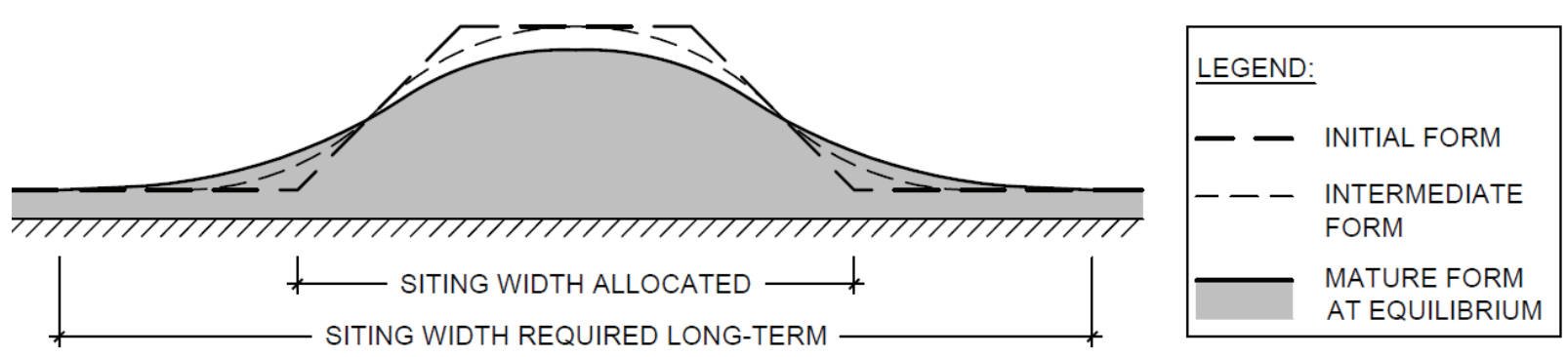

FIGURE 2: Generalized degradation of sand landforms due to physical erosion over time. 
composed of dense boreal forest and muskeg wetlands (McPherson \& Kathol, 1977). The Athabasca River flows northwards, cutting the surface minable area in two: a west and an east side, as seen in Figure 3. Native geomorphology and substrates are described in detail below.

\subsubsection{Geomorphology}

The glossary of geology defines a landform as "any physical, recognizable form or feature on the earth's surface, having a characteristic shape, and produced by natural causes; it includes major forms such as a plain, plateau, or mountain, and minor forms such as a hill, valley, slope, esker, or dune. Taken together, the landforms make up the surface configuration of the earth" (CEMA 2006).

The geomophology of the oil sands region is dictated by the last major glaciation, which occurred approximately 10,000 years ago and subsequent glaciofluvial events during melting. Glacial, glaciofluvial, and glaciolacustrine landforms and features cover the oil sands region, including drumlins, eskers, ground and hummocky moraines, meltwater channels, and proglacial lakes (Smith \& Fisher 1993; Fisher \& Smith 1994).

\subsubsection{Substrate and material type}

Surficial soil in the mineable oil sands region is of glacial origin: predominantly outwash sands and gravels, and glacial till. Glacial till is an unsorted mixture of grain sizes ranging from clay to coarse gravel that were originally eroded, entrained, transported, and subsequently deposited by glaciers. The glacial till present in ground moraines in this region tend to be high in clay content giving it a relatively low permeability. Eskers and drumlins are composed of soils ranging in texture from fine sand to coarse gravel, while proglacial lakes tend to be finer in texture, from clay to fine sand (Catto 1995). Outwash sands and gravels are widespread, particularly on the west side of the Athabasca River. It is important to note that surficial soils and their respective characteristic grain sizes are consistent over short distances and changes occur abruptly, making the landscape soils as a whole widely variable (McPherson \& Kathol, 1977).

As nature has acted on these soils, they have been altered in form. Glaciofluvial sands have been mobilized and re-worked by the wind, creating aeolian sand dunes before being re-stabilized by vegetation. Glacial till has been weathered less due to the range in particle sizes present. Wind tends to transport silt and fine sand only, and particles transported by water can find refuge in the shadow of larger particles within the till matrix. In effect, the particle size range found in the till provided an inherent resistance against small-scale erosion due to wind and rain. Naturally occuring surficial soils have been covered by thick layers (less than 10 feet to a maximum of 30 feet deep) of peat and muskeg across more than $50 \%$ of the landscape, further limiting their physical erosion (McPherson \& Kathol, 1977).

\subsection{The Anthropogenic Landscape}

The end goal of reclamation within the surface mineable AOS region is to produce a landscape that has a self-sustaining ecosystem including vegetation and wildlife common to the region (Natural Resources Canada 2015). This broad goal is stated and expanded upon to various degrees in each of the oil sands min operators' closure and reclamation plans submitted since they were first mandated seven years ago. For example, all presently active mines indicated their reclamation goal was "to achieve a maintenance-free, self-sustaining ecosystem with a capability equivalent to pre-development conditions" (CNRL 2011; Golder Associates 2011; SCE 2011 and 2012; SEI 2011); however the report for the Kearl Oil Sands Mine specifies a "locally common boreal forest ecosystem", while those for the Mildred Lake Mine, Jackpine Mine, Fort Hills Mine, and Suncor Base Mine also included the goal of recieving reclamation certification by the Alberta Government. Syn-

WEST

EAST

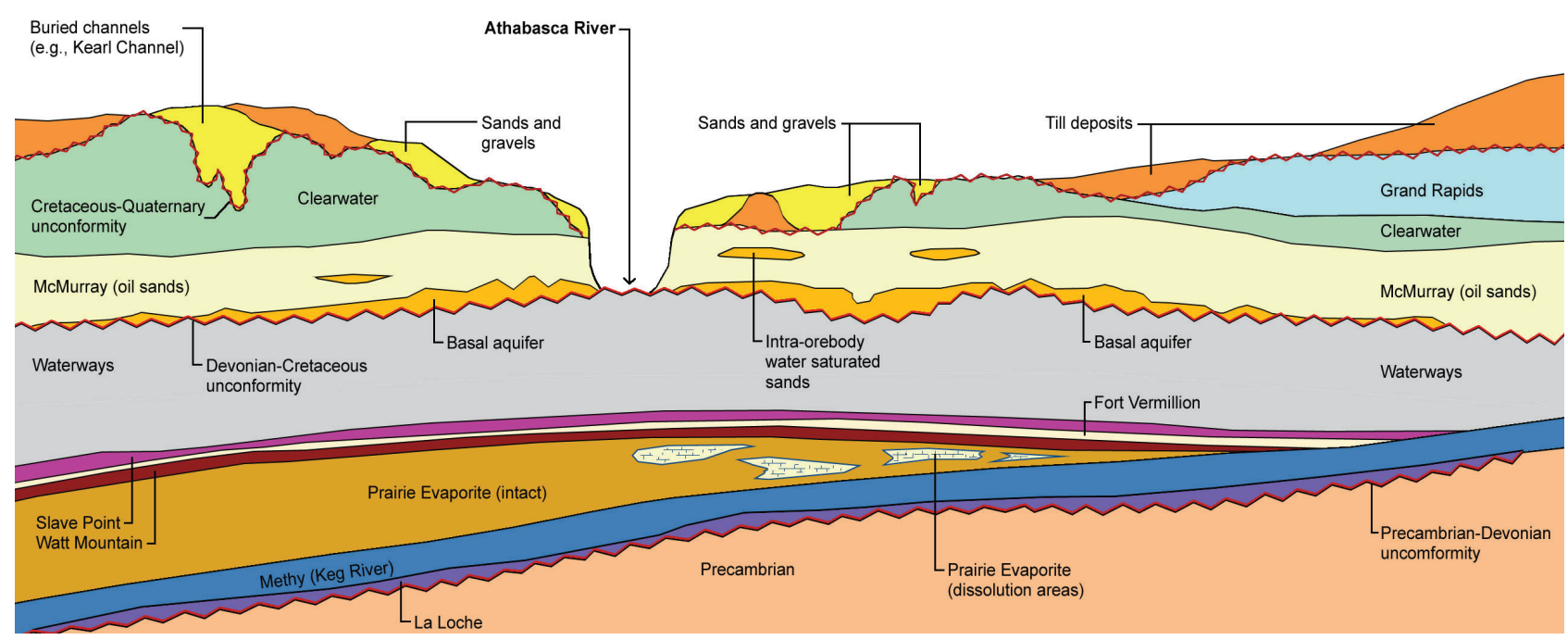

FIGURE 3: Conceptual geologic cross-section orientation from west to east in the mineable oil sands region of northern Alberta. Adapted from Shell Canada Energy, 2016. 
crude Canada Ltd, who operates two active mines in the region and one in development, went one step further to state that the closure landscape will be planned in consultation with local stakeholders and will be integrated with surrounding areas, will include boreal forest lowland and upland communities, and will yeild water suitable for release to the natural environment (SCL 2011). These reclamation goals use simple language, however, the target is rather difficult to achieve, requiring extensive collaboration among diverse professionals in order to achieve goals that have never before been achieved. Once reclamation works have taken place, an extended period of active monitoring will take place, conducting occasional maintenence as necessary. It is presently thought that once maintenance is not required for an extended period of time, and the regulator determines that the landscape poses no threat to the environment or the public in excess of naturally occuring terrain, a reclamation certificate will be provided and the post-mining landscape will be returned to the Crown (OSTDC 2014).

The following section outlines what the post-mining, pre-reclamation landscape consists of, and provides a general overview of the current approach to topographic design.

\subsubsection{Current topographic and drainage design}

While the natural topography of the oil sands mining area is quite flat, the post-mining waste-scape topography will be quite the opposite. Due to this pre-existing flat topography, dams are built around all edges with tailings placed in the middle. Closure plans indicate that above ground tailings ponds are up to $100 \mathrm{~m}$ in height with dam side slopes from 3:1 to 20:1. Tailings ponds are several hundred hectares in area, and have a relatively flat surface between the dam edges. Overburden dumps are up to 100 $\mathrm{m}$ in height as well, but tend to have steeper side slopes and cover less surface area. This topography is in stark contrast to that which naturally occurred in the AOS. In addition to aboveground waste landforms, mined out pits are proposed to be backfilled with waste. A hierarchy of constructed wetlands, lakes, and streams are propsed to transport water from high elevations to low elevations while also allowing for contaminants to be naturally removed and concentrations decreased to background levels. This will be done with targeted vegetation planting, water treatment systems, and dilution.

The topographic design of this waste-scape is in its infancy. Conventional reclamation landscapes are designed to hold a specific, pre-determined flooding interval (1 in 200 year, or 1 in 1000 year flood, for example): using this criteria given that future storm intensity is predicted to increase with climate change means that failure (exceedance of design capacity) is inevitable (Golder Associates Ltd. 2008). Overburden dumps are beginning to be designed in such a way that they mimic more natural environments, as opposed to the square pyramids more typical of historic practice. Tailings pond surfaces are beginning to be designed using a geomorphic approach once the structures near their full capacity (Ade et al 2006). Design components for pond surfaces include ridges and swales, creation of multiple watersheds, and a dendritic drainage pattern.

The perimeter dams retaining tailings ponds are presently designed prior to the start of mining, and are done so strictly with geotechnical and mining constraints in mind for the duration of infilling (Golder Associates Ltd. 2008). Changes to these designs are made continuously as the structure is raised, and as the mine plan and waste management practices change (McRoberts 2008); however long term degradation or change in shape due to geomorphic forces are not yet considered in design. As such the sides of these tailings dams have regular slopes broken up at even intervals by terraces. This is called a platform-bank topography and is illustrated in Figure 4. According to the most recent proposed mine closure plans, there are no topographic changes proposed after mining to make these slopes more natural in their shape, appearance, or in their ability to self-heal following extreme storm events.

Ideally, geomorphic design for the closure of waste structures is intended to replace the rigid uniformity and straight-line slopes used during historic mining days with a variable topography similar to an 'S-curve' that is permitted to adapt to natural environmental changes (Beersing et al. 2004, Sawatsky \& Beersing 2014). Geomorphic design in the oil sands presently imploys slope characteristics from regionally surveyed stable alluvial and vegetated channels (Golder Associates Ltd. 2008) and is applied to the reclaimed surface of a tailings pond, not to the dykes that confine the pond. The challenge in applying slopes of local-

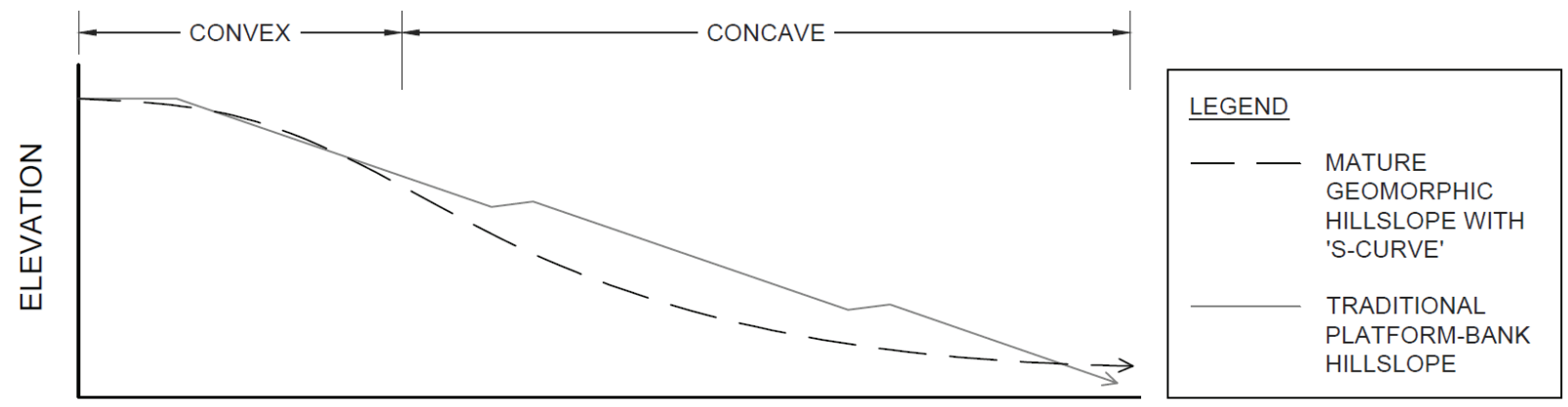

DISTANCE

FIGURE 4: Mature slope with convex and concave curve components ('S-curve') compared to a traditional platform-bank slope used on tailings dams. Adapted from Slingerland \& Beier 2016. 
ly stable terrain to the waste-scape is that the construction materials have drastically different composition, and will therefore have different stable geometry at maturity.

\subsubsection{Material and substrate types}

The terrain of the waste-scape has man-made surficial geology generated from the waste products of mining. Depending on the waste materials (tailings, overburden) to be covered, various capping materials will be used. Over $40 \%$ of the finished waste-scape (mostly tailings ponds and some in-filled pits) will be capped with coarse sand tailings (CST). CST is a fine silty sand waste product of bitumen processing. The CST cap is then proposed to be topped with $30 \mathrm{~cm}$ of peat-mineral reclamation material for vegetation to take root.

Grain size distributions (GSDs) for man-made surficial geology (CST) and similar native surficial geologies are shown in Figure 5. The range of grain sizes in CST is highly erodible by wind and water, and hence topographic design is important in protecting these landforms and their surrounding environment. Fine mineral grains tend to hide in the wind or water "flow shadow" of larger particle sizes, meaning that soils with broader GSDs tend to erode less.

It is important to note that while Figure 5 shows that similar grain size distributions exist in sand dunes and CST, the height of local sand dunes ranges from 5 to 25 meters: a fraction of the height of tailings dams and overburden waste landforms. Additionally, these local sand dunes are stabilized by more than 5 meters of dense organic matter and vegetation (McPherson \& Kathol, 1977). The greater topography of these anthropogenic structures means that they are more exposed to wind, and water has more fall height over which it can potentially erode the surface. As such, no true natural analogue for these landforms exist in the natural AOS landscape. It follows that the natural landscape may not be an appropriate tool, when used in an isolated manner, to inform design decisions for resultant mining waste landforms.

With the downstream dam topograhy unchanged at closure, an opportunity exists to estimate using empirical methods the average annual soil loss due to erosion on the downstream slope of a tailings dam. The Universal Soil Loss Equation (USLE) was first introduced by the United States Department of Agriculture (USDA) in the 1970's and subsequently revised for various applications such as construction sites (Wischmeier \& Smith 1978). The Revised Universal Soil Loss Equation For Application in Canada (RUSLEFAC) was published for use primarily in agricultural and conservation planning applications in 2002 and draws heavily upon previous work by Wischmeier \& Smith (1978) as well as new calibrations. Although RUSLEFAC does not account for erosion due to wind or gully erosion, its primary goal is to provide a long-term average annual soil loss rate for planning purposes (Wall et al. 2002). RUSLEFAC was therefore applied to a typical tailings dam downstream slope, with all the necesary parameters found to be publicly available. Parameters include rainfall and runoff $(R)$, a soil erodibility factor (K), a slope factor (LS), a vegetation management factor $(\mathrm{C})$, and a supporting practice factor $(P)$, each of which was tailored to conditions across northern Alberta. The average annual soil loss calculated using RUSLEFAC was found to be $50 \mathrm{Mg} / \mathrm{ha} / \mathrm{yr}$, which is
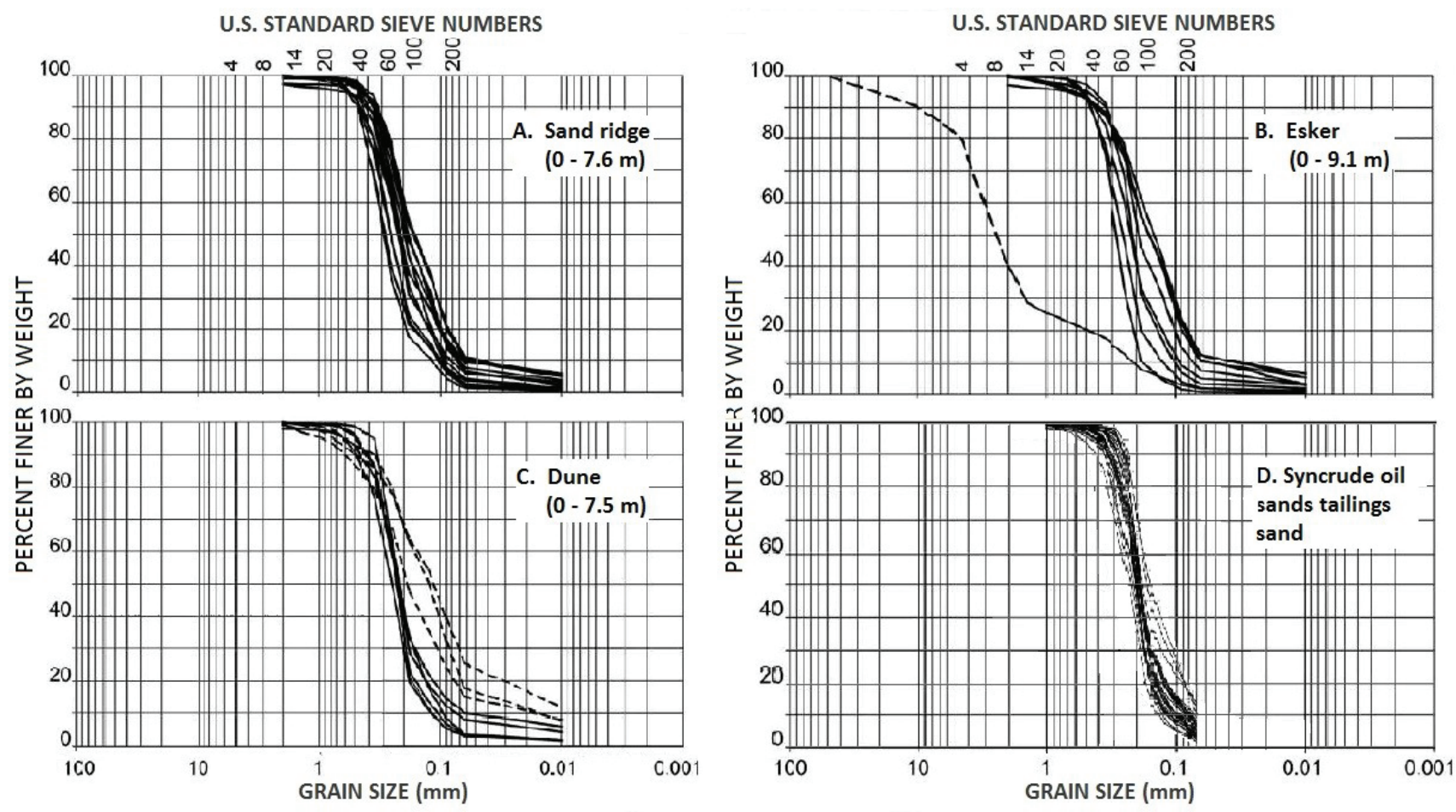

FIGURE 5: Grain size distributions for natural and artificial surficial geology in northern Alberta. Natural features in the central Boreal Plains of northern Alberta that are most similar to CST: (A) sand ridge, (B) esker, (C) sand dune, adapted from Smerdon et al. (2005). Grain size distribution for sand tailings from the Athabasca oil sands (D), adapted from McKenna (2002). 
well in excess of the canadian tollerable upper limit of 6 $\mathrm{Mg} / \mathrm{ha} / \mathrm{yr}$ (Wall et al. 2002). Post-mining slopes that have not been reclaimed have measured erosion rates ranging from $93 \mathrm{Mg} / \mathrm{ha} / \mathrm{yr}$ at the Waunafon coal mine in Wales, UK (Haig 1979) to over $400 \mathrm{Mg} / \mathrm{ha} / \mathrm{yr}$ at the Kidston gold mine in north-eastern Australia (So et al 2002). Reclamation of these downstream slopes is therefore important to the surrounding environment and long-term stability of the structures.

\section{AN ENHANCED GEOMORPHIC APPROACH FOR WASTE-SCAPE DESIGN}

While the principles of geomorphology are well understood, well documented, and selectively applied with success (Bugosh 2009), thus far the mining industry as a whole has failed to consistently design large scale landforms that are geomorphically stable. Basic erosion resistant slope profiles have been outlined (Schor \& Gray 2007; Toy \& Hadley 1987), but how do we determine specific design criteria of the mature form associated with a particular climate and surficial geology so that we might construct it?

The landscape evolution model (LEM) developed as a result of increased computing power, beginning in the 1980's in combination with advanced understanding of factors influencing erosion and sedimentation (Coulthard 2001). SIBERIA (Willgoose 1989) was the first widely used LEM making use of a digital elevation model (DEM) for topographic information. The immediate benefit of this was that an entire landform could be modelled as it was exposed to precipitation over long time frames (10 - 10,000 years). Previous empirical formulas allowed erosion from a single simplified profile to be estimated quantitatively for one year only (Wischmeier \& Smith 1978). Alternatively, one could use fallout radionuclide dating $\left({ }^{137} \mathrm{Cs}\right)$ to determine erosion rates (Hancock 2009; Hancock et al. 2011; Martinez et al. 2009).

LEM's have been tested in a range of environments to predict how the landform will degrade over time due to water-based erosion processes (Welsh et al. 2009; Verrdon-Kidd et al.2017); Welsh et al. (2009) studied erosion in the French Alps using historical records since 1826 to recreate current conditions. Verdon-Kidd et al. (2017) used a reconstructed rainfall and runoff record in order to accurately represent landform response to climate in Monsoonal north-west Australia. LEMs have been verified successfully on erosion-prone environments where end-of-construction topography is known and where the landscape has remained maintenance-free since this time (Hancock et al 2016). There are now several LEM's that predict erosion and deposition at the hillslope and catchment scale as a response to calculated runoff rates and spatially distinct soil and precipitation parameters (Coulthard 2001, Hancock et al. 2011). Most recently, fluvial erosion models have been combined with an aeolian morphology model to account for the erosive and morphological forces of wind and water together in China (Liu \& Coulthard 2015, 2017). While LEMs have been used to understand the morphology of anthropogenic waste-scapes in the past, to the authors' knowledge they have not been used proactively in order to design a geomorphically stable landform.

The enhanced geomorphic approach (outlined graphically in Figure 6) is currently being applied to a tailings pond and surrounding environment in the AOS. This approach uses the current method of applying stable slope characteristics found in locally stable environments as a first step. The resulting topographic design is then used to generate a digital elevation model (DEM) that includes the tailings pond, dams, and surrounding waste-scape within receiving watershed(s). A LEM is subsequently used to mimic degradation of the designed DEM due to fluvial erosion over extended time frames until an equilibrium topography is found. This equilibrium topography is further analysized, however the topography generated by the LEM guides surface design of the waste-scape for long-term geomorphic stability.

This approach differs from the existing approach in recognizing that waste-scapes change over time and applied geomorphic tools in a new, proactive manner to inform design. The failure mechanisms at play during active wastescape construction are different from those that dominate after reclamation: the LEM helps to determine how the waste-scape (including perimeter dams, central ponds, and overburden dumps) will morph over time. This has not been previously considered in detail.

\section{RESULTS AND DISCUSSION}

The enhanced geomorphic design approach is currently being tested in the AOS, with some unexpected and far-reaching peripheral benefits. Many of these benefits are recognized during the design stage, as the use of landscape evolution modelling forces the engineer or architect to consider the site more holistically than previous methods.

Currently adopted practices that use a geomorphic ap-

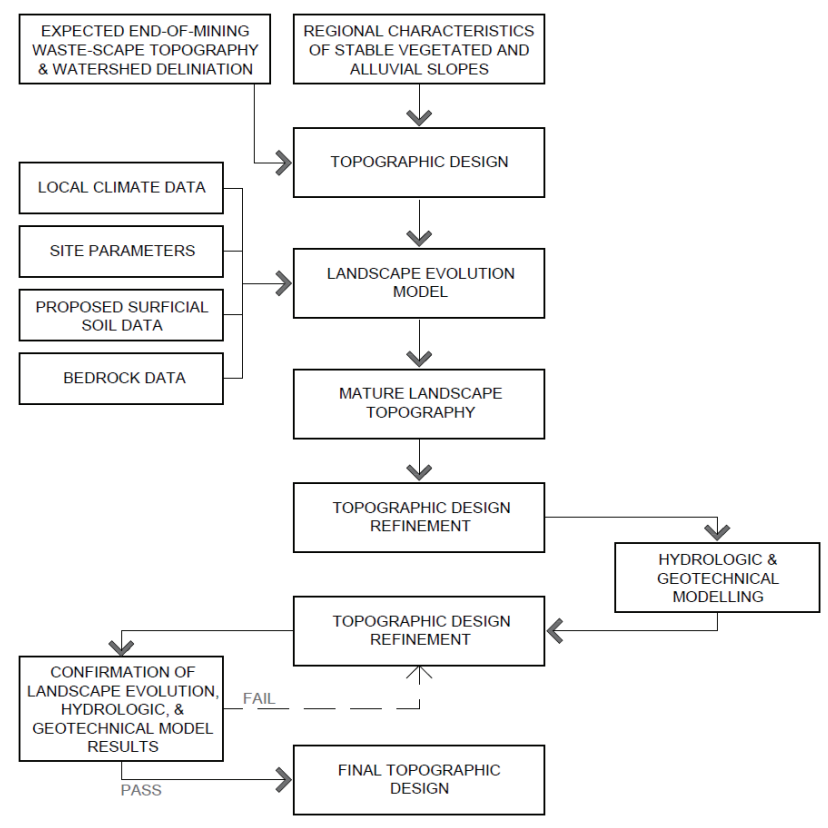

FIGURE 6: Enhanced geomorphic approach for waste-scape design. 
proach on tailings pond surfaces but not on tailings dam side slopes may lead to increased environmental loading of the surrounding environment due to sediment erosion from dams. Regardless of whether cross-sectional differences are subtle or extreme (Figure 7), given the vast $895 \mathrm{~km}^{2}$ waste-scape to be re-shaped $\left(220 \mathrm{~km}^{2}\right.$ are aboveground tailings ponds), cumulative effects are likely to be significant (Government of Alberta - Alberta Energy website).

One benefit of this process is the realization amongst landscape architects and engineers that additional space allowances are necessary for long-term stability of aboveground features compared to what was used during planning and operation: this has implications for the siting and layout of future waste-holding facilities, and their future planning for inevitable natural deterioration as opposed to its prevention.

This concept has peripheral impacts to current structures that are not presently affected by erosion and sedimentation, dune migration, or water runoff, but may be in the future (Figure 7). Additionally, the process predicts whether ongoing maintenance will be necessary to preserve the slopes that were designed without regard for long-term degradation, and which will affect the income potential of local communities, owner/ operators, or regulators tasked with monitoring and maintaining sites into the future. Where this approach is used early in the mine life, the enhanced geomorphic approach is anticipated to remove the corresponding economic strain of ongoing staffing, materials, and equipment on site post-closure.

The enhanced geomorphic approach indicates where future drainage pathways and sediment concentrations may shift to, and where additional drainage pathways are likely to develop on the landscape. While the LEM, and any model, should not be used to directly generate a design, it does inform the architect or engineer as to where addi- tional drainage capacity, erosion control measures, spatial allowances, and buffers can be best applied. Figure 7 illustrates our current approach (top left) and what that cross section might look like after modelling with a LEM (bottom left). In this example, a stream adjacent to the waste structure has been filled in/ diverted due to sediment deposition on the bottom of the slope, and soil has encroached upon a building. If LEM modelling were conducted on this wastescape design prior to construction these impacts would be understood and proactive measures could be taken to alter the design and construction.

When topography is designed with the surficial geology in mind, the resultant erosion resistance over long time frames provides stable ground for vegetation to establish and further stabilize terrain at greater depth. This means that unexpected impacts to surrounding environments are minimized. Target end landscapes can be a design challenge in mining: The enhanced geomorphic aproach encourages stakeholder coordination, reduces uncertainty regarding natural spatial projections, and provides a starting point to design from.

In the case where existing waste-scapes have been placed too close to site boundaries - whether they be natural (rivers, streams) or man-made (highways, infrastructure) - the use of a LEM over short time intervals can inform the scheduled return period for maintenance. Maintenance over extended time frames is best avoided where safe to do so; however, in many instances long-term maintenance is required and the accuracy of financial planning by corporations and governments can be improved with this knowledge. This is a long-term benefit to the companies involved, the province of Alberta and it's regulatory body that holds ultimate liability if a mining company were to go bancrupt, and tax-paying residents of Alberta.

Lastly, the geomorphic and environmental performance

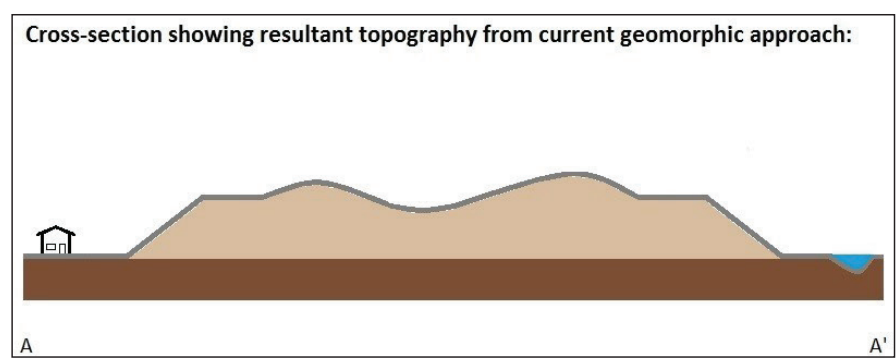

Cross-section showing potential topography generated from enhanced geomorphic approach:

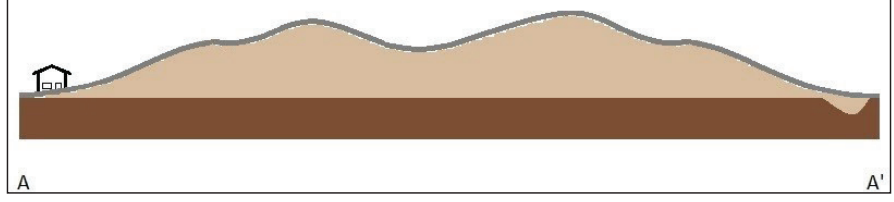

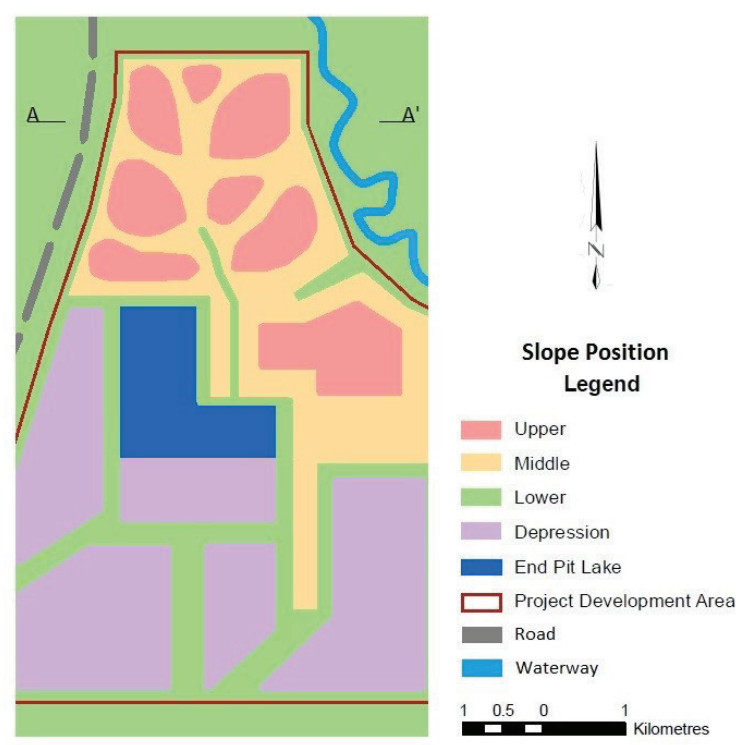

FIGURE 7: Currently adopted geomorphic approach to topographic design of waste landforms at a fictional oil sands mine on the right. Cross-sections ( $A$ - $A^{\prime}$ ) of the current geomorphic approach (top left) as compared to the same cross-section modelled using the enhanced geomorphic approach (bottom left). Note the enhanced approach provides insight as to potential long term form after decades of wind and water erosion, and impacts to adjacent infrastructure or natural features represented by the building and river. 
of waste structures in Alberta's north has a profound impact on local communities. In a 2014 study of mine closure goals and outcomes involving 143 mine closure professionals and practitioners, it was found that geotechncial factors had a cumulative impact on other reclamation goals (Baida et al 2014). Where slope stability was not optimally achieved other goals categorized under themes of 'biological', 'land-use', and 'socio-cultural' were also more likely to be unsuccessful (Baida et al. 2014; Slingerland et al. 2016). Traditional practices are inherently sustainable in their nature (Baker \& Westman 2018), and are more likely to be successfully returned to when the landscape itself is stable, and hospitable to flora and fauna.

\section{CONCLUSIONS}

Waste-scapes have been re-invented in recent years by creating adaptive re-uses at significant expense. The drive for re-purposing typically comes from large local populations such that there is economic incentive in terms of land costs/value, owner reputation, and potentially revenue generation from the waste-scape. In rural locations, smaller communities do not have the same luxury.

Waste management and design is at the core of mining: mining waste-scapes are often rurally located with small populations nearby. The historical track-record of mining companies internationally has been inconsistent with respect to closure and community relations; however, the enhanced geomorphic approach to topographic design of landforms provides a holistic design method for rural waste-scapes and a strong basis for successful future land uses.

While similar soils exist in the northern Alberta landscape, similar landforms do not: there are no natural analogues to the waste landforms generated from mining in this region. Landscape evolution models may be used as a tool to determine what these waste-scapes may eventually degrade into., An opportunity therefore exists to proactively design with the local climate and geology of the landform in question using the methodology proposed herein. An equal opportunity exists at existing rural waste-scapes that have not been proactively geomorphically designed, but where refined estimates of long-term maintenance with respect to erosion are beneficial to owners/ operators for fiscal planning.

This enhanced geomorphic approach is currently being tested in the AOS region to provide insight as to the longterm geomorphology of aboveground tailings ponds and dams. Benefits are thus far diverse and holistic in nature, providing a greater capacity than previous approaches to achieve the regions' overall goal of constructing self-sustaining local ecosystems with equivalent land capability to pre-development conditions (CNRL 2011; Golder Associates 2011; SCE 2011 and 2012; SEI 2011).

\section{ACKNOWLEDGEMENTS}

The authors would like to thank the Natural Sciences and Engineering Research Council of Canada (NSERC) and Golder Associates Ltd. for their financial support through the Industrial Postgraduate Scholarship as well as Alberta Innovates - Energy and Environment Solutions for their financial support through the NSERC Industrial Research Chair program. The authors would also like to thank the two anonymous reviewers who provided practical and beneficial feedback.

\section{REFERENCES}

Ade, F., Sawatsky, L., Beersing, A. (2006). Meeting stricter mine closure requirements naturally. Canadian Environmental Protection, 2-3.

Alberta Energy Regulator (AER). https://www.aer.ca/about-aer/spotlight-on/oil-sands. Visited May 3, 2017.

Baida, M. Slingerland, N., Wilson, G.W. (2014). The great divide between mine closure goals and outcomes, and potential solutions. International Mine Closure Conference, Johannesburg, South Africa. Oct. 1-3, 2014. Pp 1-14.

Baker, J.M., \& Westman, C.N. (2018). Extracting knowledge: Social science, environmental impact assessment, and Indigenous consultation in the oil sands of Alberta, Canada. The Extractive Industries and Society, vol. 5, 144-153.

Beersing, A.K., Dawatsky, L.F., Ade, F. (2004). A geomorphic approach for the design of drainage systems on reclaimed mine areas. Presented at the CIM conference: Edmonton, May 09 - 12, 2004.

Bugosh, N. (2009). A summary of some land surface and water quality monitoring results for constructed GeoFluv landforms. $2009 \mathrm{Na}-$ tional Meeting of the American Society of Mining and Reclamation. May 30-June 5, 2009. R.I. Barnhsel (Ed.) Published by ASMR, Lexington, KY, USA.

Canadian Natural Resources Limited (CNRL), (2011). Horizon Oil Sands Closure Conservation and Reclamation Plan. Submitted to the Alberta Energy Regulator December 20, 2011.

Catto, N. Rhoderick, \& Rutter, N. W. (1995). Dating methods for quaternary deposits. St. John's, Nfld.: Geological Association of Canada. Coulthard, T.J. (2001). Landscape evolution models: a software review. Hydrological Processes, vol. 15, 165-173.

Cumulative Environmental Management Association (CEMA). (2006). Identify, characterize \& quantify the types of landforms and landscape patterns present in the Regional Municipality of Wood Buffalo.

Fisher, T.G., Smith, D.G. (1994). Glacial Lake Agassiz: its Northwest Maximum Extent and Outlet in Saskatchewan (Emerson Phase). Quaternary Science Reviews, Vol. 13, 845-858.

Fort McKay First Nation. http://www.fortmckay.com. Visited May 3, 2017.

Golder Associates Ltd. (2008). Geomorphic characterization and design of alluvial channels in the Athabasca Oil Sands Region, Report for the Canadian Oil Sands Network for Research and Development and the Department of Fisheries and Oceans.

Golder Associates Limited, (2011). Imperial Oil Resources Ventures Limited 2011 Reclamation and Closure Plan. Submitted to the Alberta Energy Regulator December, 2011.

Government of Alberta - Alberta Energy Website. http://www.energy. alberta.ca/oilsands/791.asp Viewed May 17, 2017.

Haig, M.J. (1979). Ground retreat and slope evolution on regraded surface mine dumps, Waunafon, Gwent. Earth Surface Processes, vol. 4, 183-189.

Hancock, G.R., Coulthard, T.J., Martinez, C., Kalma, J.D. (2011). An evaluation of landscape evolution models to simulate decadal and centennial scale soil erosion in grassland catchments. Journal of Hydrology, vol. 398, 171-183.

Hancock, G.R., Lowry, J.B.C., Coulthard, T.J. (2016). Long-term landscape trajectory - Can we make predictions about landscape form and function for post-mining landforms? Geomorphology, vol. 266, 121-132.

Joly, T.L., Longley, H., Wells, C., \& Gerbrandt, J. (2018). Ethnographic refusal in traditional land use mapping: Consultation, impact assessment, and sovereignty in the Athabasca oil sands region. The Extractive Industries and Society. (Article in press)

Liu, B. Coulthard, T. J. (2015). Mapping the interactions between rivers and sand dunes:Implications for fluvial and aeolian geomorphology. Geomorphology, vol. 231, 246-257.

Liu, B. Coulthard, T. J. (2017). Modelling the interaction of aeolian and fluvial processes with a combined cellular model of sand dunes and river systems. Computers \& Geosciences, vol. 106, 1-9. 
Martin Duque, J.F., Zapico, I, Oyarzun, R., Lopez Garcia, J.A., \& Cubas, P. (2015). A descriptive and quantitative approach regarding erosiona nd development of landforms on abandoned mine tailings: New insights and environmental implications from SE Spain. Geomorphology, vol. 239, 1-16.

Martinez, C., Hancock, G.R., Kalma, J.D. (2009). Comparison of fallout radionuclide (caesium-137) and modelling approaches for the assessment of soil erosion rates for an uncultivated site in south-eastern Australia. Geoderma, vol. 151, 128-140.

McKenna, G. Thomas. (2002). Sustainable mine reclamation and landscape engineering. University of Alberta. PhD Thesis.

McPherson, R.A., Kathol, C.P. (1977). Surficial Geology of Potential Mining Areas in the Athabasca Oil Sands Region - Open File Report 1977-4 for the Alberta Research Council.

McRoberts, E. 2008. Considerations in oil sands tailings containment. In Proceedings of First International Oil Sands Tailings Conference, Edmonton, AB, 7-10 December 2008. 13-22.

Natural Resources Canada. (2015). Oil Sands: A strategic resource for Canada, North America and the global market. Cat. No. M164-4/71-2015E-PDF. ISBN 978-0-660-02164-5

Oil Sands Tailings Dam Committee (OSTDC). (2014). De-licensing of oil sands tailings dams. Technical Guidance Document. $45 \mathrm{p}$.

Richards, K. \& Clifford, N.J. (2011). The nature of explanation in geomorphology. In: The SAGE Handbook of Geomorphology, Gregory, K.J. and Goudie, A.S. (Editors). SAGE Publications Ltd. London, UK. Pp 36-58.

Rittel, H., and Webber, M. (1973). Dilemmas in a general theory of planning. Policy Sciences, Vol. 4, 155-169.

Sawatsky, L., Beersing, A. (2014). Configuring mine disturbed landforms for long-term sustainability. Proceedings of Mine Closure Solutions, 2014. April 26-30, 2014. Ouro Preto, Minas Gerais, Brazil. Infomine ISBN: 978-0-9917905-4-8. 1-13.

Schor, H.J. \& Gray, D.H. (2007). Landforming, An environmental approach to hillside development, mine reclamation, and watershed restoration. John Wiley \& Sons, Hoboken, New Jersey, USA.

Shell Canada Energy (SCE), (2011). Integrated Conservation and Reclamation Plan: Jackpine Mine - Phase 1. Submitted to the Alberta Energy Regulator December, 2011.

Shell Canada Energy (SCE). (2012). Muskeg River Mine Integrated Closure, Conservation \& Reclamation Plan. Submitted to the Alberta Energy Regulator December 2012.

Shell Canada Limited. (2016). Muskeg River Mine Life of Mine Closure Plan, EPEA and water act approval renewal application. Submitted to Alberta Energy Regulator.

Slingerland, N., Beier, N. (2016). A regional view of site-scale reclamation decisions in the Athabasca oil sands. Proceedings of IOSTC 2016, Lake Louise, AB. December 4-7. 168-177
Slingerland, N., Beier, N., Baida, M. (2016). An industry self-evaluation on geotechnical mine closure objectives and planning teams. Geotechnical News, vol. 34, 38-41.

Smerden, B.D., Devito, K.J., Mendoza, C.A. (2005). Interaction of groundwater and shallow lakes on outwash sediments in the sub-humid Boreal Plains of Canada. Journal of Hydrology, Vol. 314, 246-262.

Smith, D.G., Fisher, T.G. (1993). Glacial Lake Agassiz: the Northwestern Outlet and Paleo-flood. Geology, Vol 21, 9-12

So, H.B., Yatapanage, K., Horn, C.P. (2002). Mine-erosion: an integrated erosion and landscape design package for monitoring and modelling erosion from steep hillslopes on minespoils. 12th ISCO Conference, Beijing, 36-41.

Stedman, R.C.; Parkins, J.R.; Beckley, T.M. (2004). Resource dependence and community well-being in rural Canada. Rural Sociology, vol. 69, 213-234.

Suncor Energy Inc. (SEI), (2011). 2011 Reclamation and Closure Plan. Submitted to the Alberta Energy Regulator December 2011.

Syncrude Canada Ltd. (SCL). (2011). 2011 Mine reclamation plan and life of mine closure plan: Mildred Land and Aurora North. Submitted to the Alberta Energy Regulator December 31, 2011.

Toy, T.J. \& Hadley, R.F. (1987). Geomorphology and reclamation of disturbed lands. Academic Press, Orlando, Florida.

Toy, T.J. \& Osterkamp, W.R. (1995). The applicability of RUSLE to geomorphic studies. Journal of Soil and Water Conservation. Vol. 50(5), 495-505

Verdon-Kidd, D.C., Hancock, G.R., Lowry, J.B. (2017). A 507-year rainfall and runoff reconstruction for the Monsoonal North West, Australia derived from remote paleoclimate archives. Global and Planetary Change, vol. 158, 21-35.

Wall, G.J., Coote, D.R., Pringle, E.A., Shelton, I.J. (2002). RUSLEFAC Revised Universal Soil Loss Equation for Application in Canada. ECORC Contribution Number 02-92 / AAFC Contribution Number AAFC/AAC2244E. Agriculture and Agri-Food Canada. Ottawa, Ontario, Canada.

Welsh, K.E., Dearing, J.A., Chiverrell, R.C., Coulthard, T.J. (2009). Testing a cellular modelling approach to simulating late-Holocene sediment and water transfer from catchment to lake in the French Alps since 1826. The Holocene, vol. 19 (5), 785-798.

Willgoose, G.R., Bras R.L., Rodriguez-Iturbe, I. (1989). A physically based channel network and catchment evolution model, Dept. of Civil Engineering, MIT, Boston, MA.

Wischmeier, W.H. \& Smith, D.D. (1978). Predicting rainfall erosion losses- a guide to conservation planning. U.S. Derpartment of Agriculture, Agriculture Handbook No. 537. 